\title{
Environmental Impact Assessment of Municipal Solid Waste (MSW) Management in Florence, Italy
}

\author{
Piernicola Masella ${ }^{1}$, Lorenzo Guerrini ${ }^{1}$, Giulia Angeloni ${ }^{1}$, Alessandro Parenti ${ }^{1}$
}

\begin{abstract}
Facing the trouble of municipal solid waste (MSW) management is a rising challenge of urbanized areas. Yearly data of waste management from the city of Florence (Italy) and neighboring municipalities were gathered over 2015 year. About 412105 t of waste were collected, where 202794 $\mathrm{t}$ were mixed-waste and $72540 \mathrm{t}$ were organic. Fractions were treated in a centralized selectingcomposting plant. The outgoing materials were further treated in external plants for additional selection, composting, incineration, landfilling. The present study was aimed to assess the environmental impact of such waste management applying LCA technique. The functional unit was "one year mixed and organic waste treatment at Florence and neighboring municipalities". System boundaries included waste collection, final transport, working of the selecting-composting plant. System expansion was used to account for energy recovery (electricity) from waste. Background data were sourced from ELCD-core3-LCI database. Life cycle impact assessment (classification and characterization) was performed by ILCD midpoint method. Sixteen impact categories were computed. Focusing on global warming potential (GWP), the functional unit impacts for roughly $6.99 \mathrm{E}+8 \mathrm{kgCO} 2 \mathrm{eq}$. This figure drops to $0.212 \mathrm{E}+8 \mathrm{kgCO} 2 \mathrm{eq}$ if urban collection was not considered and further to $0.186 \mathrm{E}+8 \mathrm{kgCO} 2 \mathrm{eq}$ if final transportation was excluded. Results underline the potential benefit of on-site treatment of waste.
\end{abstract}

Keywords: urban waste, landfilling, biogas, incineration, LCA, global warming potential

\section{Introduction}

Municipal solid waste (MSW) management is a rising challenge of urbanized areas. The European Union called the imperative to follow hierarchical options for the management systems, moving from waste generation prevention to reuse preparing and recycling, to energy recovery, and only as a last option the waste disposal (Directive 2008/98/EC of the European Parliament and of the Council of 19th November 2008, on Waste). At the same time, public concerns still remain about the construction of new facilities and the adoption of new technologies. This main relies on the health matter, as consequences of direct and indirect effects of MSW management (Giusti, 2009). In this contest, Life Cycle Assessment (LCA) is an even more worldwide adopted technique to assess and compare the environmental burdens of MSW treatment strategies. Good examples are the works of Gunamantha and Sarto (2012), which study different options of MSW-to energy conversion in Indonesia, or that of Yay (2016) in Turkey. In the European contest, Jensen et al. (2016) focused on LCA of organic waste management, while Fernandez-Nava et al. (2014) compare alternatives for MSW management in Spain. At Italian level, Ripa et al. (2017) underline the importance of site-specific data for a

$\mid{ }^{1}$ Department of Agricultural, Food and Forestry Systems Management (GESAAF) - Agricultural, Forest and Biosystem Engineering Section - Università degli Studi di Firenze, Piazzale delle Cascine 15, 50144 Florence, Italy 
reliable application of LCA to MSW management, bringing as an example the city of Naples (case-study). Cherubuni et al. (2009), compare three different strategies (landfilling, sorting plant and incineration) for waste management in Rome.

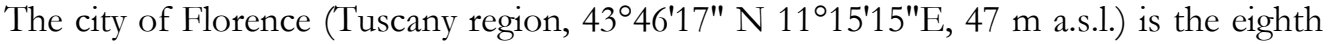
largest municipality in Italy $\left(102.32 \mathrm{~km}^{2}\right.$, population of around 380000 inhabitants at 2015) (Comune di Firenze, 2015). Sustainability data (input and output materials, energy use, transport data, emissions) of waste management (collection and treatment) from Florence and 12 other neighboring municipalities are annually published and are freely available (Quadrifoglio spa, 2015). The present study was based on data from the 2015 report. Out of total waste collected in that year, about 50\% were mixed waste and 18\% were organic. Great parts of these two fractions were treated in a centralized selectingcomposting plant. The outgoing materials (treated-MSW, organic stabilized fraction, secondary fuels, metals and leftovers) were further treated in external plants, following different fates, i.e. further selection and recovery, composting, incineration, landfilling. The study was aimed to assess the environmental impact of such waste management applying LCA technique.

\section{Building the LCA model}

According to ISO standards (International Standard Organization, ISO 1404114042-14043), a LCA study should include the four steps of goal and scope definition, life cycle inventory (LCI) analysis, assessment of the potential impacts (Life Cycle Impact Assessment, LCIA) and interpretation. The most comprehensive framework of LCA is the so-called cradle-to-grave assessment, where the full life cycle of a product in considered, from resource extraction, to use and disposal phases. A variant of the latter is the gate-to-gate assessment, where a partial life cycle assessment is performed, looking at only one value-added process in the entire production chain. Moreover, LCA studies are generally product-oriented, meaning that the functional unit selected for the study and accounting for the computed environmental burdens is usually defined in terms of the system's output, i.e. the product. By contrast, dealing with waste management asks for defining the functional unit in terms of the input to the system. Roughly speaking, a useful trick is to consider the treated-waste as the product (output) of the treatment process.

In the present work, a gate-to-gate life cycle model has been built. The functional unit was "one year mixed and organic waste treatment at Florence and neighboring municipalities". Hence, the computed impact indicators (LCIA) refer to the treatment of waste other than pre-sorted and recycled wastes, produced, collected and treated in a specific geographical region (Florence plus 12 other neighboring municipalities) in a given time (i.e. 1 year). The work was based on data published in the "2015 Sustainability Balance" by Quadrifoglio Spa (Alia Servizi Ambientali SpA, 2015). Data are freely available on the web, and cover the annual flows of materials (waste, chemicals, water) and energy (electricity, fossil fuels) needed for MSW treatment. Tables 1-5 summarize the data extracted from the report. In 2015 year a total of $412105 \mathrm{t}$ of waste were collected over the entire considered territory. Out of these, $202794 \mathrm{t}$ were mixed waste and $72540 \mathrm{t}$ were organic (Table 1). 
Table 1: Waste amount and composition for year 2015

\begin{tabular}{|l|c|c|c|}
\hline waste production & year & unit & amount \\
\hline item & 2015 & $\mathrm{t}$ & 202794 \\
\hline mixed waste & 2015 & $\mathrm{t}$ & 209311 \\
\hline pre-sorted and recycled wastes & 2015 & $\mathrm{t}$ & 412105 \\
\hline total waste & 2015 & $\mathrm{t}$ & 21335 \\
\hline pre-sorted waste glass & 2015 & $\mathrm{t}$ & 69020 \\
\hline pre-sorted waste paper and cardboard & 2015 & $\mathrm{t}$ & 16504 \\
\hline pre-sorted waste plastic, tin, etc & 2015 & $\mathrm{t}$ & 1118 \\
\hline pre-sorted metals & 2015 & $\mathrm{t}$ & 72540 \\
\hline pre-sorted organic and vegetal & 2015 & $\mathrm{t}$ & 28794 \\
\hline other & & & \\
\hline
\end{tabular}

Great parts of these two latter fractions were treated in an in-site centralized selectingcomposting plant. The outgoing materials (treated-MSW, organic stabilized fraction, secondary fuels,) were further treated in external plants, following different fates, i.e. further selection and recovery, composting, incineration, landfilling (Table 2).

Table 2: Fate of waste

\begin{tabular}{|l|c|c|c|}
\hline Fate & in-site treatment (t) & out-site treatment (t) & total (t) \\
\hline $\begin{array}{l}\text { selecting-composting } \\
\text { plant/selection* }\end{array}$ & 124950 & 38167 & 163117 \\
\hline landfilling* & 0 & 16717 & 16717 \\
\hline incineration* & 0 & 22960 & 22960 \\
\hline $\begin{array}{l}\text { selecting-composting } \\
\text { plant/composting** }\end{array}$ & 61534 & 11006 & 72540 \\
\hline total $(\mathrm{t})$ & 186484 & 88850 & 275334 \\
\hline
\end{tabular}

In short, about $50 \%$ of total wastes collected belong to pre-sorted and recycled wastes, with an organic fraction of about 18\%. The latter undergoes in-site composting (75\%) or outside composting (15\%). The mixed waste $(50 \%$ of the total) undergoes in-site selection/mechanical treatment for about $62 \%$, while about $19 \%$ follows the same fate in external plants. The remaining $8 \%$ and $11 \%$ out of the mixed waste, are out-site landfilled or incinerated, respectively.

System boundaries included mixed wastes and organic fraction collection and transport, working of the selecting-composting plant and final transport to the out-site treatments. Working of the external plants (out-site treatments) was not included because environmental burdens will weigh on those specific plants, that is on other territories.

Wastes collection was considered in terms of fossil diesel consumption for the operation. The data of total consumption was extracted from the report and scaled to the unit mass of total collected wastes. Then, the unit value has been multiplied by the amount of mixed wastes plus the organic fraction. Annual working of the selecting-composting plant requires electricity, natural gas, water and chemicals (Table 3). 
Table 3: Requirements for one-year working of the selecting-composting plant

\begin{tabular}{|l|c|c|}
\hline item & unit & amount \\
\hline total electricity & $\mathrm{kWh}$ & 6704368 \\
\hline electricity from biogas & $\mathrm{kWh}$ & 2014214 \\
\hline electricity from grid & $\mathrm{kWh}$ & 4395086 \\
\hline electricity from photovoltaic & $\mathrm{kWh}$ & 295068 \\
\hline natural gas & $\mathrm{m}^{3}$ & 9850 \\
\hline water & $\mathrm{m}^{3}$ & 11772 \\
\hline sodium hydroxide & $\mathrm{kg}$ & 10000 \\
\hline hydrogen peroxide & $\mathrm{kg}$ & 250 \\
\hline output waste water & $\mathrm{m}^{3}$ & 22260 \\
\hline
\end{tabular}

The main waste of the plant is waste water, which requires a further treatment (Table 4)

Table 4: Requirements and emissions for the treatment of waste water outgoing the selectingcomposting plant

\begin{tabular}{|l|c|c|c|c|c|}
\hline Item & unit & amount & \multicolumn{3}{|c|}{ emissions } \\
\hline waste water & $\mathrm{m}^{3}$ & 21812 & $\mathrm{NO} 3$ & $\mathrm{~kg}$ & 1.06 \\
\hline electricity consumption & $\mathrm{kWh}$ & 271691 & $\mathrm{Cd}$ & $\mathrm{kg}$ & 0.01 \\
\hline emissions & $\mathrm{kg}$ & 425.31 & $\mathrm{Cr}$ & $\mathrm{kg}$ & 0.16 \\
\hline COD & $\mathrm{kg}$ & 15.87 & $\mathrm{~Pb}$ & $\mathrm{~kg}$ & 0.05 \\
\hline BOD & $\mathrm{kg}$ & 0.26 & $\mathrm{Ni}$ & $\mathrm{kg}$ & 0.01 \\
\hline $\mathrm{NH} 3$ & $\mathrm{~kg}$ & 0 & $\mathrm{Zn}$ & $\mathrm{kg}$ & 0.13 \\
\hline $\mathrm{NO} 2$ &
\end{tabular}

Annual materials flows of the plant are further detailed in Table 5. The main output ( $40 \%$ of total) is a refuse derived fuel destined to be burned for electricity recovery. The Non-reusable fraction (20\% of total), the treated-MSW (18\% of total) and the stabilized organic fraction ( $9 \%$ of total) are destined for landfill, with recovery of electricity by biogas production. The undersized fraction is destined to a further selection/mechanical treatment. All these treatments are carried out in external plants.

Table 5: Mass balance of one-year working of the selecting composting plant.

\begin{tabular}{|l|c|c|c|}
\hline input & unit & amount & fate \\
\hline total waste & t & 186484 & in-site treatment \\
\hline mixed waste to sorting & t & 124950 & in-site treatment \\
\hline organic fraction to composting & t & 61534 & in-site treatment \\
\hline output & t & 21921 & Out-site landfilling \\
\hline treated-MSW & t & 24573 & Out-site landfilling \\
\hline Non-reusable fractions & t & 11364 & Out-site landfilling \\
\hline stabilized organic fraction & t & 13966 & Out-site mechanical biological treatment \\
\hline Undersized fraction to recovery & & 53127 & Out-site incineration \\
\hline refuse derived fuel & t & 9231 & market \\
\hline soil improver & t & 3269 & unknown \\
\hline other & t & \multicolumn{3}{|c|}{} \\
\hline total output materials & $\mathrm{t}$ & \multicolumn{3}{|l|}{} \\
\hline losses, stock and leftovers &
\end{tabular}


Data about final transport of wastes to the external plants have been extracted from the report on the base of total amount of waste transported (about $200000 \mathrm{t}$ ) during the year, the average number of travel (about 8650), the total amount of kilometers traveled (about $2000000 \mathrm{~km}$ ). This gives a final figure of roughly $50000000 \mathrm{t}^{*} \mathrm{~km}$ of transport.

The report also specifies annual requirements (materials and energy carriers) for infrastructure management, intended as yearly working of the registered/main office, operational headquarters and special waste collection centers (Table 6).

Table 6: Annual requirements (materials and energy carriers) for infrastructure management

\begin{tabular}{|l|c|}
\hline Urban infrastructures management & \\
\hline total electricity (kWh) & 1683379 \\
\hline total natural gas (mc) & 172218 \\
\hline total water $(\mathrm{mc})$ & 41913 \\
\hline
\end{tabular}

The total amounts of Table 5 were scaled to the unit amount of yearly waste collected and then multiplied by the amount of wastes corresponding to the functional unit.

The LCA model has been built in openLCA software (v. 1.5.0), a free and open source Life Cycle and Sustainability Modeling Suite by GreenDelta GmbH (Germany). Background data were sourced from ELCD core 3 LCI database (Joint Research Centre, EC). Specifically, the main following unit or system processes have been used: fuels combustion (diesel, natural gas, coal); electricity mix, Italian grid; electricity from landfill; electricity from waste incineration; electricity from photovoltaic; chemicals production (hydrogen peroxide, sodium hydroxide); articulated lorry transport ( $25 \mathrm{t}$ payload).

Foreground data about wastes production and treatment, were extracted from the cited "2015 Sustainability Balance” by Quadrifolgio spa, as detailed above. System expansion was used to account for energy recovery (electricity) from treated wastes. In detail, the system has been credited for the displacement of electricity grid production of the specific Italian mix, both for the electricity from landfill biogas and for electricity from waste incineration.

Life cycle impact assessment (LCIA, classification and characterization) was performed according to the ILCD2011 impact assessment method at midpoint level, as developed by Joint Research Centre (JRC) of the European Commission. Figure 1 gives an outline of the system model. 


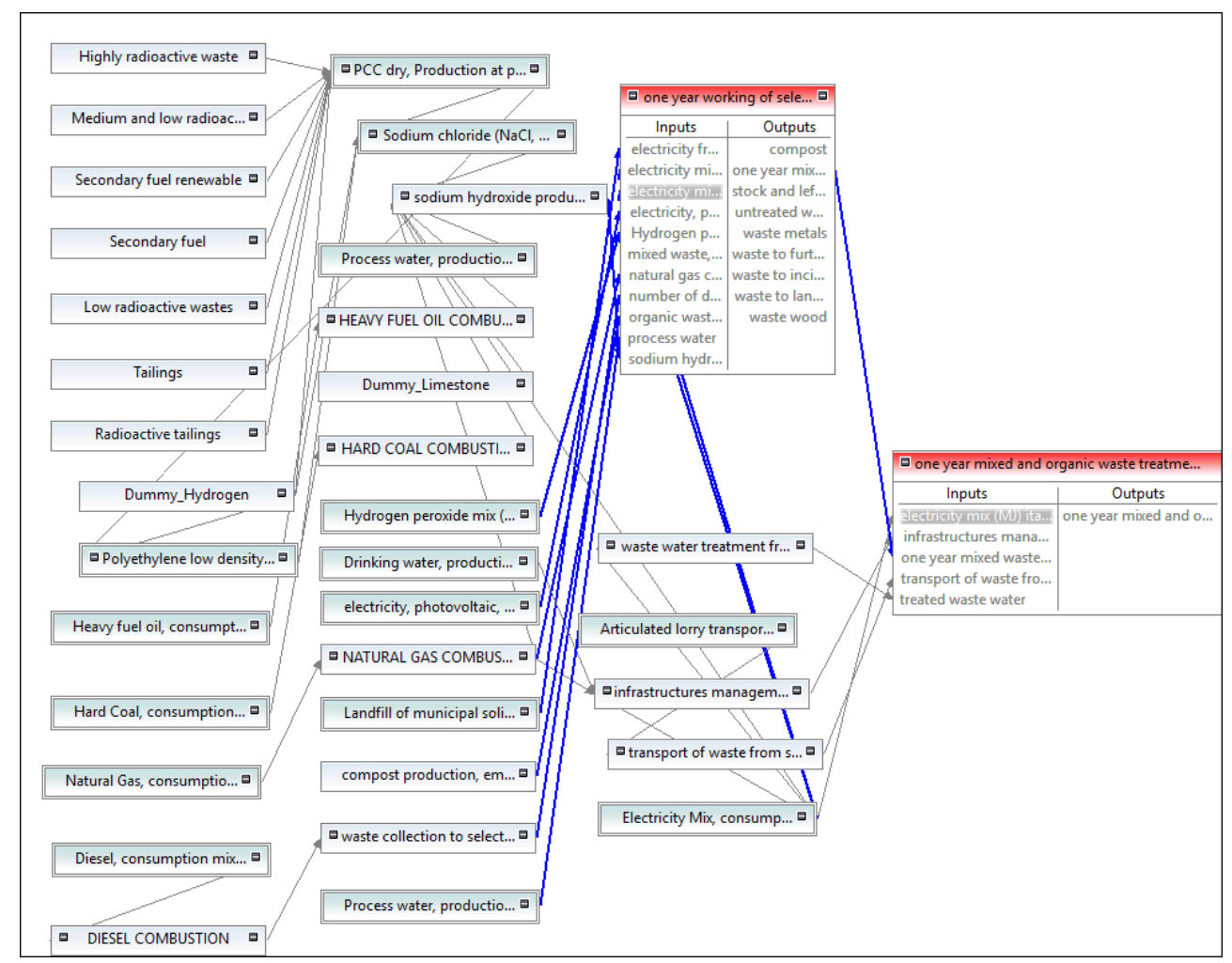

Figure 1: Structure of LCA model.

\section{Results and Interpretation}

Table 7 gives the results of LCIA for the sixteen impact indicators computed according to the ILCD2011 method. We can pay special attention on climate change by the global warming potential indicator (GWP, $\left.\mathrm{kgCO}_{2} \mathrm{eq} / \mathrm{FU}\right)$. The indicator roughly amounts to $6.99 \mathrm{E}+08 \mathrm{kgCO} 2 \mathrm{eq} / \mathrm{FU}$, corresponding to about $2500 \mathrm{kgCO} 2 \mathrm{eq}$ per ton of treated wastes. This figure is about thirty times lower than the value reported by Ripa et al. (2017). Probably, both the different assumptions used for the construction of the model (e.g. system boundaries, allocation choices) and the different impact methods, contribute to this discrepancy. By contrast, our result is consistent with findings of Cherubini et al. (2009), where a very similar scenario (mixed wastes and organic fraction treated in a selecting/composting plant) gives a GWP of 7.04E+8 $\mathrm{kgCO} 2 \mathrm{eq}$ on yearly base. The magnitude of our GWP is also consistent with the range computed by Fernandez-Nava et al. (2014), varying between about 30 and $4600 \mathrm{kgCO} 2 \mathrm{eq} / \mathrm{t}$ of treated waste. A useful benchmark to understand the scale of the our result is the Italian Greenhouse Gas Inventory 1990 - 2015, National Inventory Report 2017 (ISPRA 2017), where the Italian waste sector has been accounted for a total equivalent emission of $1.88 \mathrm{E}+10 \mathrm{kgCO} 2 \mathrm{eq}$ for the 2015 year. Our GWP for the same year represents about $3.7 \%$ of this figure. Moreover we can crosscheck our finding by computing the per capita GWP potential due to the waste sector, via dividing the total equivalent emission 
of the sector $(1.88 \mathrm{E}+10 \mathrm{kgCO} 2 \mathrm{eq})$ by the Italian population of 2015 year $(60.73 \mathrm{E}+6$ inhabitants). The resulting per capita amounts of $3.09 \mathrm{E}+02 \mathrm{kgCO} 2 \mathrm{eq} /$ inhabitant, can be multiplied by the population of the territory under study $(6.54 \mathrm{E}+05)$, thus obtaining a final estimate of $2.02 \mathrm{E}+08 \mathrm{kgCO} 2 \mathrm{eq} / \mathrm{FU}$, which represent an average indirect estimate of GWP imputable to our functional unit. This latter figure is about 3.5 times lower than the GWP computed in our study, indicating that our assessment may be overestimated. However, it should be noted that the Italian waste management strongly differs among territories, either on regional scale or national scale.

Table 7: Impact indicators coming from LCIA computation (ILCD2011 midpoint method)

\begin{tabular}{|l|c|c|c|}
\hline Impact category & $\begin{array}{c}\text { with } \\
\text { collection }\end{array}$ & $\begin{array}{c}\text { without } \\
\text { collection }\end{array}$ & Reference unit \\
\hline Acidification & $1.671 \mathrm{E}+07$ & $6.86 \mathrm{E}+06$ & Mole H+ eq. \\
\hline Climate change & $6.996 \mathrm{E}+08$ & $2.12 \mathrm{E}+07$ & $\mathrm{~kg} \mathrm{CO}$ eq. \\
\hline Freshwater ecotoxicity & $1.265 \mathrm{E}+07$ & $-4.20 \mathrm{E}+05$ & CTUe \\
\hline Freshwater eutrophication & $1.435 \mathrm{E}+03$ & $1.28 \mathrm{E}+03$ & $\mathrm{~kg}$ P eq. \\
\hline Human toxicity - carcinogenics & $1.186 \mathrm{E}-01$ & $2.31 \mathrm{E}-02$ & CTUh \\
\hline Human toxicity - non-carcinogenics & $1.059 \mathrm{E}+00$ & $-2.65 \mathrm{E}-01$ & CTUh \\
\hline Ionizing radiation - ecosystems & $6.000 \mathrm{E}+00$ & $-1.04 \mathrm{E}+01$ & CTUe \\
\hline Ionizing radiation - human health & $6.787 \mathrm{E}+05$ & $-9.85 \mathrm{E}+05$ & $\mathrm{~kg}$ U235 eq. \\
\hline Land use & $2.144 \mathrm{E}+09$ & $2.14 \mathrm{E}+09$ & $\mathrm{~kg}$ SOC \\
\hline Marine eutrophication & $5.365 \mathrm{E}+06$ & $1.20 \mathrm{E}+06$ & $\mathrm{~kg} \mathrm{~N} \mathrm{eq.}$ \\
\hline Ozone depletion & $3.669 \mathrm{E}-01$ & $-1.00 \mathrm{E}+00$ & $\mathrm{~kg}$ CFC-11 eq. \\
\hline Particulate matter/Respiratory inorganics & $3.892 \mathrm{E}+05$ & $2.19 \mathrm{E}+05$ & $\mathrm{~kg}$ PM2.5 eq. \\
\hline Photochemical ozone formation & $1.422 \mathrm{E}+07$ & $3.29 \mathrm{E}+06$ & $\mathrm{~kg}$ C2H4 eq. \\
\hline Resource depletion - mineral, fossils and renewables & $1.109 \mathrm{E}+02$ & $2.76 \mathrm{E}+01$ & $\mathrm{~kg} \mathrm{Sb} \mathrm{eq.}$ \\
\hline Resource depletion - water & $-4.104 \mathrm{E}+06$ & $1.32 \mathrm{E}+07$ & $\mathrm{~m} 3$ \\
\hline Terrestrial eutrophication & $6.175 \mathrm{E}+07$ & $1.61 \mathrm{E}+07$ & Mole N eq. \\
\hline
\end{tabular}

Contribution analysis reveals that over 95\% of total GWP comes from the waste collection process. Data about the latter process have been extracted from the report with some uncertainty. In fact, the report gives the total amount of diesel consumed (about $2421341 \mathrm{~kg}$ ) for waste collection plus the processes entailed in the urban cleaning, without discrimination among the two operations. By analyzing the composition of machineries available for the two processes (waste collection and urban cleaning), a reasonable share of 0.68 for collection out of the total consumption, has been assumed. This gives about $4.73 \mathrm{E}+07 \mathrm{~kg} / \mathrm{FU}$ of diesel. Obviously, GWP is extremely sensitive to diesel consumption, so much so that if collection is excluded from the system boundaries, GWP drops to $0.212 \mathrm{E}+8 \mathrm{kgCO} 2 \mathrm{eq} / \mathrm{FU}$ (Table 7), while a decreasing sharing of diesel consumption gives intermediate results (Figure 2). Interestingly, by halving the diesel share (i.e. from 0.68 to 0.34 ) the computed GWP approach the value reported by ISPRA (2017). As expected, all the indicators are sensitive to the waste collection via the diesel combustion process (Table 7 and Figure 2). Once the collection process is excluded, contribution analysis reveals that the main contributing processes are the waste transport to the out-side treatments and, above all, the infrastructure management (Figure 3). This pattern is almost common to most of the indicators. For the categories 
Freshwater ecotoxicity, Human toxicity - carcinogenics, Human toxicity - noncarcinogenics, Ionizing radiation - ecosystems, Ionizing radiation - human health, Marine eutrophication, Ozone depletion, Particulate matter/Respiratory inorganics, Photochemical ozone formation, Resource depletion - mineral, fossils and renewable, and Terrestrial eutrophication, the most impacting process is the infrastructure management. Specifically for acidification and Particulate matter/Respiratory inorganics, the infrastructure management account for over $90 \%$, while about $10 \%$ is due to emissions from compost production. For Freshwater ecotoxicity, Human toxicity - noncarcinogenics, Photochemical ozone formation, and Resource depletion - mineral, fossils and renewable, final transport to the out-side treatments is the most relevant process. For freshwater eutrophication, the most significant process is landfilling. The latter is also important for Human toxicity - carcinogenics, while for Ionizing radiation ecosystems and Ozone depletion, the waste water treatment from the selectingcomposting plant is significant via the grid electricity consumption. Finally, the importance of the transport process is also detectable by excluding the final transportation of waste to the out-site treatments, i.e. assuming that all the treatments may be carried out in-site. In this case, the GWP drops to $0.186 \mathrm{E}+8 \mathrm{kgCO} 2 \mathrm{eq} / \mathrm{FU}$, with a potential saving of about $10 \%$.

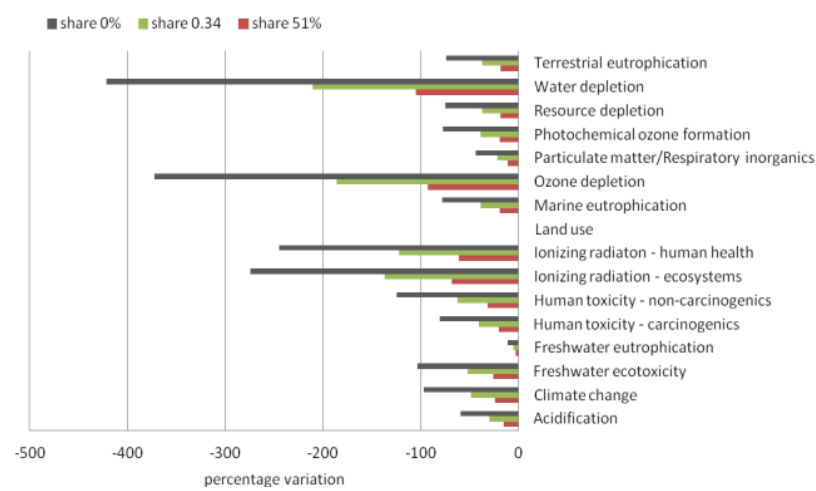

Figure 2: Sensitivity of indicators to the waste collection process. Variations refer to a diesel consumption share of 0.68 among collection and urban cleaning operation.

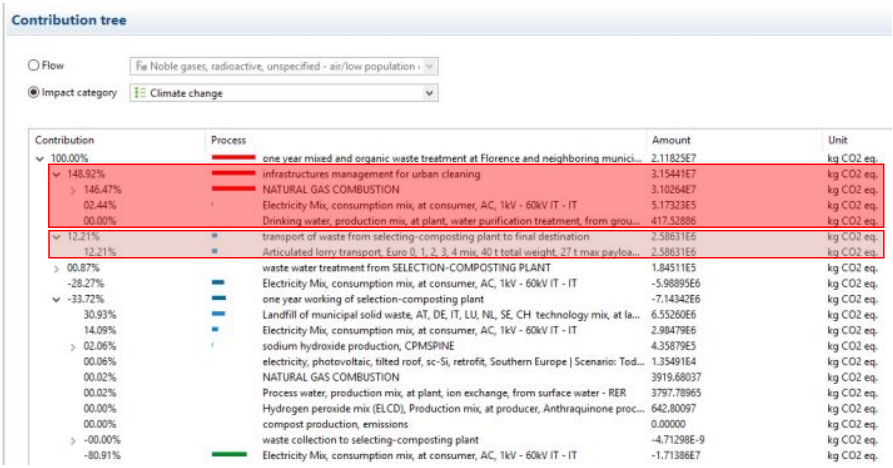

Figure 3: Contribution tree of aggregated processes to GWP indicator, as extracted from the software. 


\section{Conclusions}

The built LCA model allows an estimate of potential environmental impact of waste management sector in Florence (Italy). The greater uncertainty belongs to the assessment of waste collection and transport process. This confirms that a substantial reduction of environmental burdens may be achieved by moving towards increased efficiencies of transports in the urban area, such as lighter vehicles, more efficient engines, improved fuels or increasing degree of hybridization (electricity) and cleaner/more-sustainable biofuels. At the same time, environmental impact may be reduced by planning the implementation of new local plant for in-site treatment of waste. Finally, the present work also showed that an important part of the impact is due the infrastructure management, thus underlining the need of an in-depth revision/audit of the organization and management of these structures.

\section{References}

Cherubini, F., Bargigli, S., \& Ulgiati, S. (2009). Life cycle assessment (LCA) of waste management strategies: Landfilling, sorting plant and incineration. Energy, 34(12), 2116-2123. doi:10.1016/j.energy.2008.08.023

Comune di Firenze (2015). Retrieved from http://statistica.fi.it/opencms /opencms/MenuPrincipale/Dati/Popolazione_Firenze/index.html?comune=firenze

Fernández-Nava, Y., Río, J. D., Rodríguez-Iglesias, J., Castrillón, L., \& Marañón, E. (2014). Life cycle assessment of different municipal solid waste management options: A case study of Asturias (Spain). Journal of Cleaner Production, 81, 178-189. doi:10.1016/j.jclepro.2014.06.008

Giusti, L. (2009). A review of waste management practices and their impact on human health. Waste Management, 29(8), 2227-2239. doi:10.1016/j.wasman.2009.03.028

Gunamantha, M., \& S. (2012). Life cycle assessment of municipal solid waste treatment to energy options: Case study of KARTAMANTUL region, Yogyakarta. Renewable Energy, 41, 277-284. doi:10.1016/j.renene.2011.11.008

ISPRA. Italian Greenhouse Gas Inventory 1990 - 2015, National Inventory Report 2017 (Rep. No. 261).

Jensen, M. B., Møller, J., \& Scheutz, C. (2016). Comparison of the organic waste management systems in the Danish-German border region using life cycle assessment (LCA). Waste Management, 49, 491 504. doi:10.1016/j.wasman.2016.01.03

Quadrifoglio Spa (by Alia Servizi Ambientali SpA) (2015) Bilancio di sostenibilità 2015. Retrieved from http://www.quadrifoglio.org/

Ripa, M., Fiorentino, G., Vacca, V., \& Ulgiati, S. (2017). The relevance of site-specific data in Life Cycle Assessment (LCA). The case of the municipal solid waste management in the metropolitan city of Naples (Italy). Journal of Cleaner Production, 142, 445-460. doi:10.1016/j.jclepro.2016.09.149

Yay, A. S. (2015). Application of life cycle assessment (LCA) for municipal solid waste management: A case study of Sakarya. Journal of Cleaner Production, 94, 284-293. doi:10.1016/j.jclepro.2015.01.089 